\title{
Dissolved organic carbon and nitrate flows in two micro- watersheds with different land uses
}

\section{Fluxos de carbono orgânico dissolvido e de nitrato em duas microbacias sob diferentes usos}

\author{
Tulio Gonçalves dos Santos ${ }^{1 *}$; Ricardo Santos Silva Amorim²; Edwaldo Dias \\ Bocuti' ; Oscarlina Lúcia dos Santos Weber ${ }^{3}$; Letycia Cunha Nunes ${ }^{4}$
}

Highlights

Cerrado micro-watershed shows lower water retention and higher peak flow.

Land use modifies the dissolved organic carbon (DOC) and nitrate $\left(\mathrm{NO}_{3}\right)$ flows.

Increments of $\mathrm{DOC}$ and $\mathrm{NO}_{3}$ on rainy days are higher in the agricultural watershed.

\begin{abstract}
The impacts of human activities on watersheds can change the quality and possible uses of water resources. In this context, we evaluated the flows of dissolved organic carbon ( $\mathrm{DOC})$ and nitrate $\left(\mathrm{NO}_{3}\right)$ in the surface waters of two micro-watersheds with different anthropic impacts. Water samples were collected from two microwatersheds with different land uses (regenerated savanna and an agricultural site) from January 2014 to April 2015. In the rainy season, the samples were collected every 15 days, while in the dry season, samples were collected every 30 days. An automatic sampler in the stream collected the composed samples. Water flow was monitored with a sensor that measured the hydraulic load on the sill of the triangular spillway installed in each micro-watershed. The $\mathrm{DOC}$ and $\mathrm{NO}_{3}$ contents were analyze via UV-Vis spectrophotometry. The flow was estimated based on the $\mathrm{DOC}$ and $\mathrm{NO}_{3}$ flows and concentrations. The DOC concentrations were higher in the Cerrado micro-watershed; however, there was no difference in $\mathrm{NO}_{3}$ concentrations. In both watersheds, there was a significant increase in the concentrations of $\mathrm{DOC}$ and $\mathrm{NO}_{3}$ on rainy days, with was more pronounced in the agricultural watershed. The $\mathrm{DOC}$ and $\mathrm{NO}_{3}$ flows were higher in the micro watershed with Cerrado vegetation on days with rain; while on days without rain, there was no difference.
\end{abstract}

Key words: Land use. Hydrology. Hydrological monitoring. Nutrient flow.

1 Doctoral Students of the Graduate Program in Tropical Agriculture, Federal University of Mato Grosso, UFMT, Cuiabá, MT, Brazil. fellows CAPES. E-mail: tuliogsantos@hotmail.com; ed.bocuti@hotmail.com

2 Prof. Associate, Agricultural Engineering Department, Federal University of Viçosa, DEA/CCA/UFV, Viçosa, MG, Brazil. E-mail: rsamorim@ufv.br

3 Profa Associate, Department of Soil and Agricultural Engineering, Faculty of Agronomy and Animal Science, UFMT, Cuiabá, MT, Brazil. E-mail: oscsanweb@gmail.com

${ }^{4}$ Master in Tropical Agriculture, UFMT, Cuiabá, MT, Brazil. E-mail: letyciacn@gmail.com

* Author for correspondence

Received: May 17, 2020 - Approved: Sept. 30, 2020 


\section{Resumo}

Os impactos das atividades humanas realizadas sobre microbacias hidrográficas podem alterar a qualidade e os possíveis usos do recurso hídrico. Neste contexto, o objetivo deste estudo foi avaliar os fluxos de carbono orgânico dissolvido (COD) e nitrato $\left(\mathrm{NO}_{3}\right)$ nas águas superficiais de duas microbacias hidrográficas com diferentes impactos antrópicos. Para tal, foram realizadas coletas de amostras de água em duas microbacias com uso distintos do solo, Cerrado regenerado e uma área agrícola, no período de janeiro/2014 a abril/2015. As amostras de água foram coletadas quinzenalmente no período chuvoso e mensalmente no período seco. As amostras compostas foram coletadas com amostrador automático instalado nos cursos d'água. O monitoramento da vazão foi realizado através de um sensor de nível que registrou a carga hidráulica vertente na soleira do vertedouro triangular instalado em cada uma das microbacias. Os teores de $\mathrm{COD}$ e de $\mathrm{NO}_{3}$ foram analisados em um espectrofotômetro UV-Vis. O fluxo foi estimado com base nos valores de vazão e das concentrações de $\mathrm{COD}$ e NO${ }_{3}$. As concentrações de COD são maiores na microbacia Cerrado, porém não houve diferença nas concentrações de $\mathrm{NO}_{3}$. Em ambas as microbacias há incremento significativo da concentração de $\mathrm{COD}$ e de $\mathrm{NO}_{3}$ nos dias com chuva, sendo este incremento maior na microbacia agrícola. Os fluxos de $\mathrm{COD}$ e de $\mathrm{NO}_{3}$ são maiores na microbacia com vegetação de Cerrado na presença de chuva, porém não houve diferença na ausência de chuva.

Palavras-chave: Uso e ocupação do solo. Hidrologia. Monitoramento hidrológico. Fluxo de nutrientes.

\section{Introduction}

Studies on water quality changes in micro-watersheds are crucial to understand the impacts of different land uses on the aquatic environment. In the last decades, the Cerrado biome has been extensively modified by humans, with considerable impacts on its hydrological dynamics.

Theincreasinguse of chemicalfertilizers in this region has largely compromised water quality, with excessive nutrients reaching aquatic systems near cropping areas.

Of these, nitrate is considered a major pollutant, affecting water quality and (Galloway et al., 2008).

When nitrogen is applied to soil in the form of ammonia $\left(\mathrm{NH}_{3}\right)$, it is rapidly transformed into ammonium $\left(\mathrm{NH}_{4}{ }^{+}\right)$and, when not used by crops or microorganisms, is subsequently. Nitrate form weak chemical bonds with soil colloids, and when not absorbed by plants, it is lost via soluviation or denitrification processes (Kaiser, Reinert, Reichert, Streck, \& Pellegrini, 2010).

Apart from nitrate, dissolved organic carbon (DOC) is another important parameter to evaluate the effect of anthropization on water resources. Generally, DOC in the watercourse stems from biological or physicalchemical processes, such as dissolution and soluviation of particulate organic matter or the decomposition of animals and plants (Creed, Webster, \& Burbonniere, 2013). It can interfere with the acidity of aquatic ecosystems (Eshleman \& Hemond, 1985) and increase metal transport, resulting in the formation of organic complexes which can enhance the toxicity of metals in aquatic biota. Beyond that, the DOC represents almost $50 \%$ of the carbon flow exported to the oceans and is one important compound of the carbon global cycle, making it closely connected with climatic 
and environmental changes (Smith, Kaushal, Beaulieu, Pennino, \& Welty, 2017).

To understand the dynamics of DOC and $\mathrm{NO}_{3}$ in micro-watersheds, monitoring is extremely important. In this context, we evaluated the flows of $\mathrm{DOC}$ and $\mathrm{NO}_{3}$ in two micro-watersheds from the Das Mortes River.

\section{Materials and Methods}

This study was performed in Campo Verde, which is located in the south-eastern part of the state of Mato Grosso. The climate is tropical savanna climate, with a rainy season between October and April and a dry season between May and September. Average annual precipitation is 1.800 , with an average temperature ranging from 18 to $24^{\circ} \mathrm{C}$ (Meister Nóbrega, Rieger, Wolf, \& Gerold, 2017; Nóbrega et al., 2017).
We selected two micro-watersheds with different land uses (regenerated Cerrado and agricultural site) typical for the study area. The micro-watershed used for agricultural purposes (M-AGRO) covered an area of 135,4 ha and was located in the Santa Luzia Farm

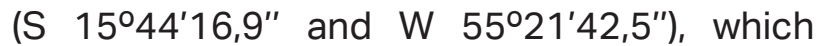
cultivates soybean (summer harvest) and corn (winter harvest) in succession. The fertilizers are applied onto the soil without incorporation.

The Cerrado micro-watershed (M-CER) had secondary Cerrado vegetation (more than 20 years of regeneration) and covered an area of 78 ha. It was located within the Rancho do Sol Farm (S $15^{\circ} 47^{\prime} 42,7^{\prime \prime}$ and W $55^{\circ} 20^{\prime} 16,6^{\prime \prime}$ ).

The Table 1 shows the soil characteristics of the two studied microwatersheds.

\section{Table 1}

Physical and physical-hydric characterization of the soil attributes in the analyzed micro-watersheds, Campo Verde - MT, Brazil

\begin{tabular}{|c|c|c|c|c|c|}
\hline \multirow[t]{2}{*}{ Attributes } & \multirow[t]{2}{*}{ Depth (cm) } & \multicolumn{2}{|c|}{ M-CER } & \multicolumn{2}{|c|}{ M-AGRO } \\
\hline & & Mean & *SD & Mean & SD \\
\hline \multirow{4}{*}{ Clay (\%) } & $00-10$ & 12.12 & 5.95 & 56.76 & 9.52 \\
\hline & $10-20$ & 10.49 & 2.62 & 52.84 & 7.49 \\
\hline & $20-40$ & 11.31 & 0.77 & 56.18 & 10.84 \\
\hline & $40-60$ & 11.88 & 1.19 & 60.36 & 5.19 \\
\hline \multirow{4}{*}{ Silt (\%) } & $00-10$ & 2.44 & 2.24 & 15.59 & 6.21 \\
\hline & $10-20$ & 1.89 & 1.61 & 21.21 & 7.81 \\
\hline & $20-40$ & 1.27 & 0.48 & 18.45 & 5.91 \\
\hline & $40-60$ & 1.87 & 0.91 & 19.60 & 5.05 \\
\hline \multirow{4}{*}{ Sand (\%) } & $00-10$ & 85.45 & 8.01 & 27.64 & 14.24 \\
\hline & $10-20$ & 87.62 & 4.02 & 25.95 & 12.10 \\
\hline & $20-40$ & 87.42 & 1.02 & 25.38 & 13.43 \\
\hline & $40-60$ & 86.24 & 0.83 & 20.05 & 3.47 \\
\hline
\end{tabular}


contuation...

\begin{tabular}{|c|c|c|c|c|c|}
\hline \multirow{4}{*}{ Microporosity (\%) } & $00-10$ & 18.09 & 6.29 & 48.39 & 4.55 \\
\hline & $10-20$ & 15.24 & 4.56 & 43.62 & 5.52 \\
\hline & $20-40$ & 15.87 & 5.11 & 41.84 & 5.92 \\
\hline & $40-60$ & 16.88 & 6.11 & 44.66 & 4.23 \\
\hline \multirow{4}{*}{ Macroporosity (\%) } & $00-10$ & 31.16 & 4.13 & 12.08 & 5.70 \\
\hline & $10-20$ & 30.57 & 5.29 & 13.80 & 4.24 \\
\hline & $20-40$ & 27.02 & 4.74 & 16.10 & 5.55 \\
\hline & $40-60$ & 25.17 & 6.10 & 12.19 & 3.71 \\
\hline \multirow{4}{*}{ Total porosity (\%) } & $00-10$ & 49.26 & 3.87 & 60.47 & 5.96 \\
\hline & $10-20$ & 45.81 & 2.06 & 57.42 & 4.04 \\
\hline & $20-40$ & 42.89 & 3.01 & 57.94 & 5.73 \\
\hline & $40-60$ & 42.05 & 0.94 & 56.86 & 4.87 \\
\hline \multirow{4}{*}{ Field capacity (\%) } & $00-10$ & 16.47 & 5.97 & 39.55 & 4.69 \\
\hline & $10-20$ & 13.42 & 4.67 & 36.44 & 5.34 \\
\hline & $20-40$ & 14.72 & 4.44 & 35.11 & 5.77 \\
\hline & $40-60$ & 15.63 & 5.23 & 36.77 & 4.04 \\
\hline \multirow{4}{*}{$\begin{array}{l}\text { Hydraulic conductivity } \\
\qquad\left(\mathrm{mm} \cdot \mathrm{h}^{-1}\right)\end{array}$} & $00-10$ & 531.1 & 206.9 & 54.5 & 72.5 \\
\hline & $10-20$ & 498.4 & 331.2 & 185.0 & 151.6 \\
\hline & $20-40$ & 515.3 & 291.1 & 92.0 & 145.3 \\
\hline & $40-60$ & 407.7 & 260.3 & 52.0 & 78.1 \\
\hline \multirow{2}{*}{ Total organic carbon (\%) } & $00-20$ & 0.94 & 0.62 & 2.60 & 0.26 \\
\hline & $20-40$ & 0.60 & 0.43 & 1.47 & 0.20 \\
\hline \multirow{2}{*}{ Total nitrogen (\%) } & $00-20$ & 0.05 & 0.03 & 0.14 & 0.03 \\
\hline & $20-40$ & 0.04 & 0.02 & 0.09 & 0.01 \\
\hline Slope (\%) & & 5.2 & 29.1 & 1.68 & 8.3 \\
\hline
\end{tabular}

SD: standard deviation.

\section{River flow monitoring}

Monitoring of the river flow started in January 2014 and ended in March 2015. In the rainy season, from November to April, data collection and water sampling were performed every 15 days, while in the dry season, we sampled every 30 days.

For river flow monitoring, we installed metal triangle spillways on the control section of the micro-watersheds, which contained a multiparameter probe Hydrolab, DS5X model, to continually monitor the piezometric head above the spillway sill. The probe estimates the piezometric head of the water channel as a function of hydrostatic pressure.

The probes were installed at $2 \mathrm{~m}$ upstream of the spillway, where the water level is lower, to avoid interference with the piezometric head. Water level was measured in 10-min intervals. 


\section{Calculation of river flow and specific river flow}

To converse the outflow water level height above the sill into river flow, we used the Kindsvater-Shen equation (Equation 1) and its calibration adjustment functions (Equations 2 and 3):

$$
\begin{aligned}
& Q=\frac{8}{15} C_{e} \sqrt{2 g} \tan \tan \left(\frac{\theta}{2}\right) h e^{\frac{5}{2}} \\
& K h=0.001[\theta(1.395 \theta-0.05734)+4.135] \\
& C_{e}=\theta(0.02286 \theta-0.05734)+0.6115
\end{aligned}
$$

Here, $Q$ is the spillway outflow $\left(\mathrm{m}^{3} \mathrm{~s}^{-1}\right)$, $\mathrm{Ce}$ is the effective discharge coefficient to the triangle spillway (dimensionless), $\theta$ is the spillway angle (radian), $\mathrm{h}$ is the water level above the spillway sill, $\mathrm{Kh}$ is the adjustment factor of the outflow, and he is the effective water level outflow $(h+K h)$.

Based on the specific river flow, we compared the two micro-watersheds. is the specific river flow is the quantity of water produced by the drainage area and can be calculated as follows (Equation 4):

$Q_{e}=\frac{Q}{A}$,

where $Q_{e}=$ specific river flow, in $L s^{-1}$ ha-1 $^{-1} Q=$ river flow in $L^{-1}$, and $A=$ watershed drainage area in ha.

\section{Precipitation monitoring}

In each micro-watershed, we installed three pluviometers with a tipping bucket, which recorded the precipitation height every 10 minutes. In this way, based on the precipitation data and on the analyzed water variables, we evaluated the changes in the micro-watershed during rain events.

\section{Water sampling}

At the control section of each microwatershed, we installed an automatic water sampler (BL2000 ${ }^{\circledR}$, Hach-Lange $\left.\mathrm{GmbH}\right)$, which contained 24 1-L bottles. Automatic sampling was performed simultaneously with water level measurements to represent basis flow or flow during rain. The chosen interval was 14.4 hours for each extraction of $200 \mathrm{~mL}$, with five samples over 72 hours to fill a 1-L bottle.

Flow sampling during rain was activated by the increase in water level via a hydrostatic level sensor (FD-01, Profimess), which was connected to the automatic sampler to drive the water sample each time when the watercourse level changed by $5 \mathrm{~cm}$. Each sampling event lasted for 5 minutes, filling a 1 - L water bottle in 30 .

Each bottle was filled during one program, which means that as soon as the second program was activated, the automatic sampler selected one bottle different bottle of that one that was being filled during the first program. Prior to collecting the bottles for laboratory analysis, we downloaded information related to the sampling time and program.

Samples were collected every 10 days and packed in a cool box with ice, according to the recommendations of the National Sample Collection and Preservation Guide (Agência Nacional de Águas [ANA], 2011).

\section{Preparation and analysis of water samples}

The DOC and $\mathrm{NO}_{3}$ analyses were performed in the ecophysiology laboratory of the Federal University of Mato Grosso. For this, we used $200 \mathrm{~mL}$ of the water samples, 
which were filtered through $0.45-\mu \mathrm{m}$ fiberglass filters without organic resin (Whatman, with a diameter of $47 \mathrm{~mm}$ ), so that only the dissolved carbon organic fraction was analyzed.

To speed up filtration, we used a Millipore filtration system with a vacuum pump. After filtration, the samples were analyzed using a UV-Vis spectrophotometer (Spectrolyser; Scan, Austria) at an absorption spectrum of 200 to $750 \mathrm{~nm}$. The $\mathrm{NO}_{3}$ and DOC concentrations were calculated based on the absorbance spectrum of each sample, using the ANAPro software.

\section{Calculation of dissolved organic carbon (DOC)} and nitrate $\left(\mathrm{NO}_{3}\right)$

The DOC and $\mathrm{NO}_{3}$ flows represent the transported quantity of these substances to the micro-watershed outlet. The flow was obtained by means of the concentrations of $\mathrm{DOC}, \mathrm{NO}_{3}$ and the specific river flow, using the following equation:

$\mathrm{Fluxo}_{\mathrm{COD} \text { ou } \mathrm{NO}_{3}}=C_{\mathrm{COD} \text { ou NO}} \times Q_{e}$,

where the flow is represented in $\mathrm{g} \mathrm{ha}^{-1} \mathrm{~S}^{-1}, \mathrm{C}$ is the concentration of $\mathrm{DOC}$ and $\mathrm{NO}_{3^{\prime}}$ in $\mathrm{g} \mathrm{L}^{-1}$; and Qe is the specific flow, in $L^{-1} \mathrm{ha}^{-1}$.

\section{Statistical data analysis}

To determine the relationship between water quality parameters in the dry and rainy seasons, we performed Pearson's correlation analysis. The correlation coefficients were obtained at a significance level of $5 \%$, using the statistical software IBM ${ }^{\circledR}$ SPSS $^{\circledR} 17$.

\section{Results and Discussion}

Figure $1 \mathrm{~A}-\mathrm{B}$ shows the distribution of the rain events for both micro-watersheds. The total amount of precipitation during this study was about $1.300 \mathrm{~mm}$, with distinct dry and rainy seasons. In the M-CER, we measured 74 days with rain, while the M-AGRO received rain on 82 days.

In both watersheds, the dry season occurred between April and September; isolated rain events accounted for 5.4 and $8.3 \%$ of the annual precipitation at the M-AGRO and M-CER watersheds, respectively.

\section{Specific river flow in the micro-watersheds}

Figure 1 C-D shows the hydrograph with the specific river flow variation $(Q e)$ on days with and without rain for M-AGRO and M-CER. Several factors, such as precipitation, can modify the river flow behavior in a micro watershed. As the pluviometric patterns of both watersheds were similar, without intervention with watercourses, the differences in the hydrological behavior are related to the soil characteristics of the micro-watersheds (Table 1).

Menezes, Prado, Silva, Mansur and Oliveira (2009) stated that the higher river flows found in the rainy season are because the water inflow into groundwater is higher than the quantity lost to the atmosphere. The authors highlight that in the dry season, the groundwater recharge is affected due to the low quantity of precipitation and the greater water use by plants, in addition to higher evapotranspiration, resulting in a lower base flow. 
We noted a difference between the mean values of specific flow between the watersheds as well as the measured flow during days with and without rain. In the micro-watershed M-CER, the specific river flow increased by around $78 \%$ in the days with rain, while in the $M-A G R O$, this increase was only $57 \%$.

The higher increase in the specific river flow in the M-CER can be related to the sandy soil, with a sand content of more than $85 \%$, a high hydraulic conductivity, a low water retention capacity, and high permeability and slope (Table 1). In this way, during rain events, water percolates more easily through the soil profile, also because of the higher slope in this watershed (Table 1) and the subsurface and base flow get the watercourse in lower time, which resulted in the difference between the base flows and peak between the microwatersheds.

Generally, micro-watersheds with pasture and native vegetation are characterized by sandy soils, with good permeability and water infiltration (Bocuti, Amorim, Santos, Di Raimo, \& Pereira, 2019). The M-CER, despite having a soil with high infiltration capacity, had a low water retention capacity, allowing water infiltration and percolation; as a result, water transportation to the watercourse is increased, which led to a $285 \%$ higher river flow on days with rain (Figure 1-D).
DOC and $\mathrm{NO}_{3}$ concentrations and flow in the micro-watersheds

The average DOC and $\mathrm{NO}_{3}$ concentrations, measured in the surface water of the micro-watersheds in the periods with and without rain, are shown in Figure 2 $A-B$. The obtained values in this study are according to the range of values observed by Toledo and Nicolella (2002).

Based on Figure 2-A, M-CER had higher DOC concentrations in the periods with and without rain, mainly because of its sandy texture and higher slope. These factors contribute to soluviation processes in the soil and the surface waters, which are intensified via rain. 

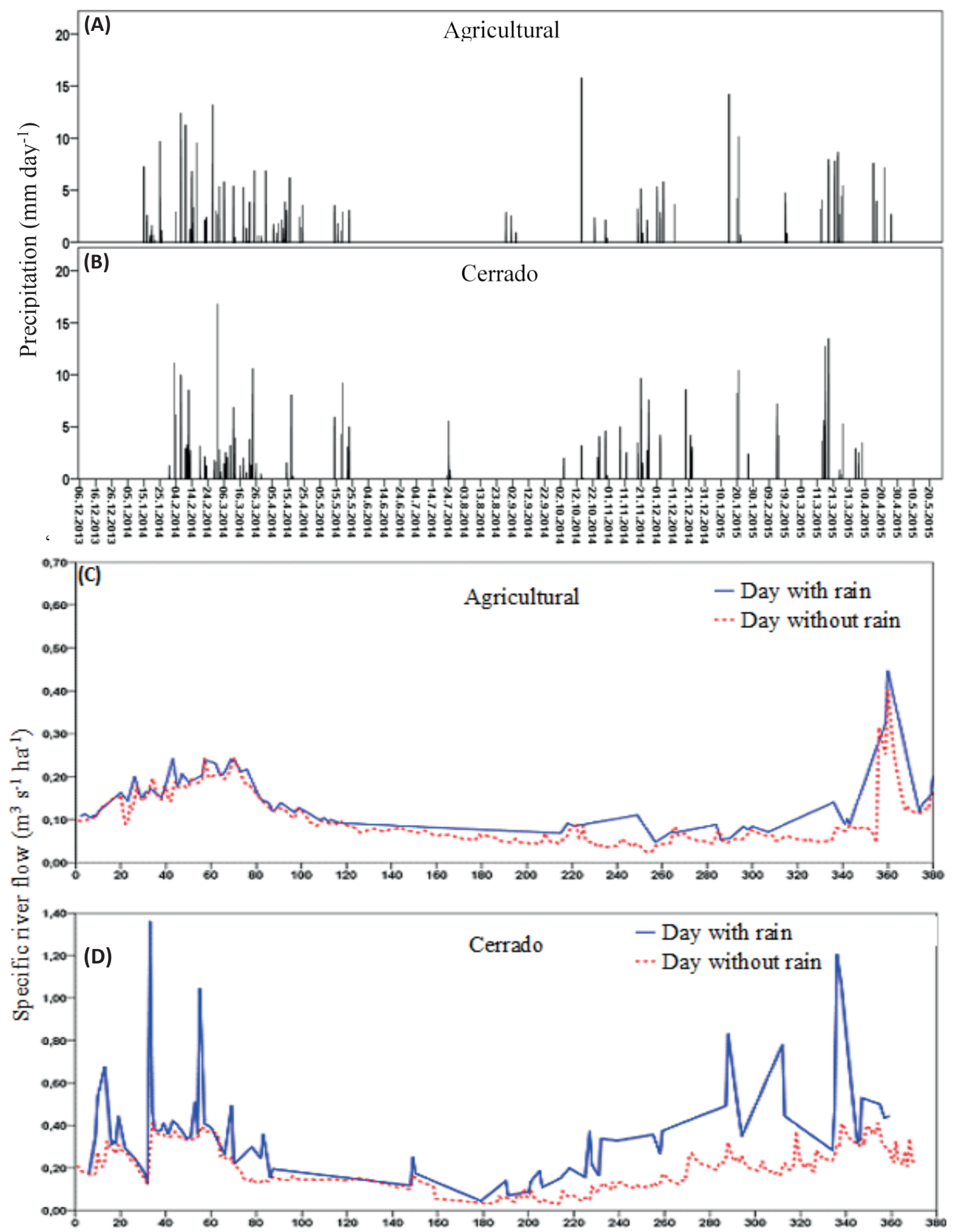

Figure 1. Daily precipitation (Agricultural - A and Cerrado - B) and hydrograph of the observed daily specific river flow in the days with and without rain in the agricultural (C) and Cerrado (D) micro-watersheds. 



Figure 2. Concentration and flow of dissolved organic carbon - $\mathrm{DOC}(\mathrm{A}$ and $\mathrm{C})$ and nitrate $-\mathrm{NO}_{3}(\mathrm{~B}$ and $D$ ) in the surface waters of the Cerrado and agricultural micro-watersheds on days with and without rain. *Different capital letters indicate a significant difference between micro-watersheds; different lowercase letters indicate a significant difference within the same micro-watershed. 
Both watersheds had increased levels of $\mathrm{DOC}$ and $\mathrm{NO}_{3}$ on days with rain, which is in agreement with the findings of Ríos-Villamizar, Rios and Waichman (2011) and Lopes and Magalhães (2010). The M-AGRO (DOC - 225\% and $\left.\mathrm{NO}_{3}-90 \%\right)$ had higher increases than M-CER (DOC - 127\% and $\mathrm{NO}_{3}-66 \%$ ), which can be explained by the differences in soil characteristics (Table 1). The soil in M-AGRO was more clayey, with an average clay content of approximately $53 \%$ in the $0-60-\mathrm{cm}$ soil layer, a higher microporosity, an higher water retention capacity, and a lower permeability. During the rainy season, in some places, we observed groundwater outcropping, indicating an increased soil moisture.

Because of the higher clay content and microporosity, the soil of M-AGRO was less susceptible to the soluviation of solutes such as NO3 and DOC. However, due to its lower hydraulic conductivity and macroporosity (Table 1), resulting in lower permeability, this soil was more prone to runoff, which probably intensified the transportation of $\mathrm{DOC}$ and $\mathrm{NO}_{3}$ into the watercourse.

The increase in DOC concentration with the increase in precipitation is common in the rainy season. Andrietti et al. (2016) also observed an increase in DOC during the period of higher river flow, associated to a higher washing out of the surface layers through the runoff.

Countway, Canuel and Dickhut (2007) highlighted that erosion and runoff are the main sources of organic and inorganic compounds in watercourses. During transport, organic matter can be modified through biotic and abiotic processes, such as photo-oxidation, adsorption and desorption, microbial respiration, flocculation, precipitation, and immobilization in the sediments, thus contributing to particulate and dissolved carbon.

In the M-CER, the lower increment of $\mathrm{DOC}$ and $\mathrm{NO}_{3^{\prime}}$ on days with rain might be a result of lower runoff volumes.

According to Beltrame (1994), the physical soil characteristics, such as texture, porosity, and depth, influence rainfall infiltration capacity and runoff velocity, which affect erosivity processes.

The soil of M-CER had a higher sand content and a higher hydraulic conductivity (about 10 times more at the 0-10-cm-layer), with a higher macroporosity and a lower microporosity (Table 1). These characteristics result in a lower water retention, a higher permeability, and a higher infiltration capacity. Therefore, at rain events with the same intensity, the runoff volume is lower in M-CER, reducing $\mathrm{DOC}$ and $\mathrm{NO}_{3}$ inputs.

According to Beltrame (1994), vegetation coverage, apart from protecting the soil against the impacts of raindrops, promotes porosity and soil permeability, thereby reducing runoff volume and velocity. Because M-CER had a perennial vegetation, the effect of vegetation in this site was more pronounced when compared to M-AGRO with a more seasonal vegetation.

Combined with rain, DOC flows into the watersheds were higher. The M-CER received higher DOC inputs, both on days with and without rain (Figure 2-C).

Regarding the $\mathrm{NO}_{3}$ flow, although the levels were similar for days with and without rain, $\mathrm{NO}_{3}$ flow into $\mathrm{M}$-CER was higher (Figure 2-D). Considering that the $\mathrm{NO}_{3}$ flow is obtained by the product of the specific river flow and 
the concentration of the compound, the higher $\mathrm{NO}_{3}$ flows must be the higher observed specific river flow in $\mathrm{M}-\mathrm{CER}$.

\section{Conclusions}

The micro-watershed with Cerrado vegetation had a higher specific flow and a higher increment on days with rain when compared to the watershed with agricultural production

The DOC concentrations were higher in the Cerrado micro-watershed.

There was no difference in the $\mathrm{NO}_{3}$ concentrations between the two microwatersheds.

In both micro-watersheds, there was a significant increase in $\mathrm{DOC}$ and $\mathrm{NO}_{3}$ concentrations on days with rain.

On days with rain, the $\mathrm{DOC}$ and $\mathrm{NO}_{3}$ flows were higher in the micro-watershed with Cerrado vegetation.

\section{Acknowledgments}

We thank the Santa Luzia Farm for providing the study sites. CAPES provided a Master scholarship to the first author. This research was developed in partnership with the CarBioCial project (01 LL0902A). The authors also acknowledge FAPEMAT (Support to Research Fund of Mato Grosso State, www. fapemat.mt.gov.br; project: 335908/2012) and CNPq (National Council for Scientific and Technological Development, www.cnpq.br; project 481990/2013-5) for financial support. We thank the field-trip assistants Dan Estevão Rocha, lanna Marília Alves, and Alan R. R. Martins.

\section{References}

Agência Nacional das Águas (2011). Guia nacional de coleta e preservação de amostras: água, sedimento, comunidades aquáticas e efluentes líquidos.

Andrietti, G., Freire, R., Amaral, A. G., Almeida, F. T., Bongiovani, M. C., \& Schenider, R. M. (2016). Índices de qualidade da água e de estado trófico do rio Caiabi, MT. Revista Ambiente \& Água, 11(1), 162-175. doi: 10.4136/ambi-agua.1769

Beltrame, A. V. (1994). Diagnóstico do meio físico de bacias hidrográficas: modelo e aplicação. Editora da UFSC, 1(1), 112.

Bocuti, E. D., Amorim, R. S. S., Santos, T. G., Di Raimo, L. A. D. L., \& Pereira, H. G. (2019). Erodibilidade entressulcos e sua relação com atributos de solos do Cerrado. Revista de Ciências Agrárias de Portugal, 42(1), 68-78. doi: 10.19084/RCA18130

Countway, R. E., Canuel, E. A., \& Dickhut, R. M. (2007). Sources of particulate organic matter in surface waters of the York River, VA estuary. Organic Geochemistry, 38(3), 365-379. doi: 10.1016/j. orggeochem.2006.06.004

Creed, F. I., Webster, K., Braun, G., \& Burbonniere, R. (2013). Topographically regulated traps of dissolved organic carbon create hotspots of soil carbon dioxide efflux in forests. Biochemistry, 112(1), 149-164. doi: 10.1007/s10533-012-9713-4

Eshleman, K. N., \& Hemond, H. F. (1985). The role of organic acids in the acid-base status of surface waters at Bickford watershed, Massachusetts. Water Resources, 21(10), 1503-1510. doi: 10.1029/WR021i010 p01503 
Galloway, J. N., Townsed, A. R., Erisman, J. W., Bekunda, M., Cai, Z., Frenei, J. R., Martinelli, L. Z., \& Seitzinger, S. (2008). Transformation of the nitrogen cycle: recent trends, questions and potential solutions, Science, 320(5878), 889-892. doi: 10.1126/science.1136674

Kaiser, D. R., Reinert, D. K., Reichert, J. M., Streck, C. A., \& Pellegrini, A. (2010). Nitrate and ammonium in soil solution in tobacco management systems. Revista Brasileira de Ciência do Solo, 34(2), 379-388. doi: 10.1590/S0100-06832010000200011

Lopes, F. W. A., \& Magalhães, A. P. M. (2010). Influência das condições naturais de $\mathrm{pH}$ sobre o índice de qualidade das águas (IQA) na bacia do Ribeirão de Carrancas. Geografias, 6(2), 34-147. doi: 10.5281/ zenodo. 2655928

Meister, S., Nóbrega, R. L. B., Rieger, W., Wolf, R., \& Gerold, G. (2017). Process-based modelling of the impacts of land use change on the water balance in the Cerrado Biome (Rio das Mortes, Brazil). Erdkunde, 71(3), 241-266. doi: 10.3112/ erdkunde.2017.03.06

Menezes, J. M., Prado, R. B., Silva., G. C. S., Mansur, K. L., \& Oliveira, E. S. (2009). Qualidade da água e sua relação espacial com as fontes de contaminação antrópicas e naturais: bacia hidrográfica do rio São Domingos - RJ. Revista Engenharia Agrícola, 29(4), 687-698. doi: 10.1590/S0100-69162009000400019
Nóbrega, R. L. B., Guzha, A. C., Torres, G. N., Kovacs, K., Lamparter, G., Amorim, R. S. S.,... Gerold, G. (2017). Effects of conversion of native cerrado vegetation to pasture on soil hydro-physical properties, evapotranspiration and streamflow on the Amazonian agricultural frontier. Plos One, 12(6), 1-12. doi: 10.1371/journal. pone.0179414

Ríos-Villamizar, E. A., Martins, A. F., \& Waichman, A. V. (2011). Caracterização físico-química das águas e desmatamento na bacia do rio Purus, Amazônia Brasileira Ocidental. Revista Geografia Acadêmica, 5(2), 54-65. doi: 10.2495/WS130021

Smith, R. M., Kaushal, S. S., Beaulieu, J. J., Pennino, M. J., \& Welty, C. (2017). Influence of infrastructure on water quality and greenhouse gas dynamics in urban streams. Biogeosciences, 14(11), 28312849. doi: 10.5194/bg-14-2831-2017

Toledo, L. G., \& Nicolella, G. (2002). Índice de qualidade de água em microbacia sob uso agrícola e urbano. Scientia Agricola, 59(1), 181-186. doi: 10.1590/S010390162002000100026 